\title{
固相分光法とその流れ分析への応用
}

\author{
松岡 史郎 ${ }^{1}$, 吉村 和久 $^{\circledR 2}$
}

\section{Solid-Phase Spectrometry and Its Application to Flow Injection Analysis}

\author{
Shiro MATSUOKA $^{1}$ and Kazuhisa Yoshimura ${ }^{2}$ \\ ${ }^{1}$ Department of Environmental Science, Faculty of Science, Niigata University, Ikarashi, Niigata-shi, Niigata \\ $950-2181$ \\ ${ }^{2}$ Department of Chemistry, Faculty of Sciences, Kyushu University, 4-2-1, Ropponmatsu, Chuo-ku, Fukuoka- \\ shi, Fukuoka $810-8560$
}

(Received 4 August 2005, Accepted 18 September 2005)

\begin{abstract}
Solid-phase spectrometry (SPS) is based on the direct spectrometric measurement of solid phase which has sorbed a sample component. Direct application of the method mekes it possible to determine trace components in water samples without preconcentration. This method could be applied to a new type of FIA detection system, in which on-line detection with solidphase retention of analytes is carried out. The sensitivity enhancement is easily accomplished by increasing the sample volume introduced. Analytes present in the $\mu \mathrm{g} \sim \mathrm{sub}-\mu \mathrm{g} \mathrm{dm}{ }^{-3}$ range can be easily determined by using this system. The fundamental background and applicability of SPS and FI-SPS are described.
\end{abstract}

Keywords : solid phase; spectrometry; flow analysis; high sensitivity; speciation.

\section{1 はじめに}

固相抽出法は，様々な試料の中からの目的成分の前濃縮 や，他の共存する成分からの分離技術として多くの分析法 に用いられている. しかし, 定量操作のためにいったん脱 着を行わなければならず，必ず希釈を伴うことになる。し たがって, 脱着せずに目的成分に関する物理量を固相で直 接分光測定できれば, 高感度化を容易に達成できることに なる。この点に着目して開発を行ったのが固相分光法であ る.

固相分光法の原点は, 1950 年代に藤本, 垣花らにより 開発された樹脂点滴法 ${ }^{12)}$, すなわち少量の溶液に数粒の イオン交換樹脂を加え, その樹脂の着色を目視により観察 する微量分析法にある.この方法はイオン交換反応を利用 できるため選択性には優れているが，その応用は定性分析

\footnotetext{
${ }^{1}$ 新潟大学理学部自然環境科学科：950-2181 新潟県新潟市五十 嵐 2 の町 8050

2 九州大学大学院理学研究院化学部門: 850-8560 福岡県福岡市 中央区六本松 4-2-1
}

に限定されていた。この濃縮固相の着色を定量分析に用い ることを可能にしたのが固相分光法である．当時，固相の 光吸収を透過光により測定することは, その散乱バックグ ラウンドの大きさゆえに不可能であると考えられていた. しかし, 光路幅を $1 \mathrm{~mm}$ にすれば, 市販の吸光光度計で十 分定量が可能であることを見いだしたのである.

固相分光法としての最初の報告は, イオン交換体比色法 (ion exchanger colorimetry) である ${ }^{34)}$. この方法は，水 試料中の微量成分に対し有機試薬を添加することで呈色化 学種とし, イオン交換体などの固相に濃縮して直接吸光定 量を行うものである。一度濃縮した目的成分を再溶出する 必要がなく, 水試料中の sub- $\mu \mathrm{g} \mathrm{dm}{ }^{-3}$ レベルまでの微量成 分分析には非常に有効であることが確認された。このバッ チ法による固相分光法は，紫外域 ${ }^{5)}$ に対しても拡張された 後，検出法に関しては吸光光度法以外に，例えば蛍光法 ${ }^{6)}$ や光音響法 ${ }^{7)}$, 分析対象では天然水などの水試料以外に医 薬品や農薬などにまで, その適用範囲が広がっている. 更 に，ごく少量の固相を充填したフローセルの開発により， 流れ分析の検出法としても発展を遂げている ${ }^{8) \sim 10)}$. 
固相の分光測定を用いた定量法は固相分光法（solid phase spectroscopy，SPS）として，また流れ分析との組み 合わせは固相分光流れ分析法 (flow injection-solid phase spectroscopy, FI-SPS）という名称で世界的に認知される ようにもなった．著者らはSPS の開発から FI-SPSへの展 開まで，長年にわたってかかわってきた。本稿では，測定 に関する基本原理やはん用性に関してその概要を述べると ともに, 現在進行中の研究についても紹介する.

\section{FI-SPS の基礎}

\section{$2 \cdot 1$ 測光の原理}

吸光光度法を例にとって SPS における高感度化の仕組 みを概説する。目的とする着色成分を吸着・濃縮した固相 を充填したセルを，ダブルビーム分光光度計のセルホルダ ーに設置し，空気対照で測定したときに観測される吸光度 值 $A$ の内訳は次のようになる.

$$
A=A_{\mathrm{RC}}+A_{\mathrm{RL}}+A_{\mathrm{S}}+A_{\mathrm{R}}+A_{\mathrm{C}}
$$

ここで， $A_{\mathrm{RC}} ， A_{\mathrm{RL}} ， A_{\mathrm{S}}$ はそれぞれ目的着色成分，共存 する呈色試薬，樹脂間障に存在する平衡溶液による吸光度 である。また， $A_{\mathrm{R}}$ は固相の吸収・散乱バックグラウンド, $A_{\mathrm{C}}$ はセルによる吸収・散乱バックグラウンドを示す。希 薄溶液を扱う場合 $A_{\mathrm{S}}$ は無視できる。 $A_{\mathrm{R}}$ には固相による吸 収や散光（表面反射や拡散反射等により散乱され検出器に 入射しない光）が関与し, 固相の種類, セルと検出器との 位置関係（セルと検出器との距離が遠い場合，固相の透過 光は散光により検出器に届きにくくなる）などがその要因 となる。目的成分の吸着に起因する $A_{\mathrm{RC}}$ を試料溶液濃度 に対してプロットすることで，検量線を作成して定量を行 うが，同一条件で作成した空試験を対照とすることや，別 に測定した空試験スペクトルを差し引くことにより， $A_{\mathrm{RC}}$ を知ることが可能となる。ただし，バッチ法の場合には， 固体がセルに対し常に同じ状態で充填されるとは限らない ので， $A_{\mathrm{R}}$ は測定の度に変動し，それが測定誤差を引き起 こすことになる。この問題点は 2 波長（目的成分の吸収 極大波長と非吸収波長）における $A$ を測定し, その差 $\Delta A$ を用いることにより克服することができた，一方，後述の 流れ分析の場合では，フローセル内に充填された常に同一 の濃縮媒体を定量に用いるため， $A_{\mathrm{R}}$ の変動は小さい.

\section{$2 \cdot 2$ バックグラウンドの低減}

SPS では， $A$ に対する $A_{\mathrm{R}}$ の寄与が大きい。 また光路部 断面積の小さなフローセルを用いる場合には， $A_{\mathrm{C}}$ の寄与 も無視できない，固相の透過光測定が難しいのは，これら の総計が, 吸光度スケールで通常の分光光度計がカバーで きる 3 を超えることもあるからである。したがって， $A_{\mathrm{R}}$
をいかに小さくできるかが，本法の適用範囲を決める要因 になる。 $A_{\mathrm{R}}$ の低減を図るためには，固相の透過散乱光を できるだけ光検出器の受光部に導くための工夫が必要とな る. 光検出器の受光部がセル室に近接したタイプの分光光 度計を使用する場合には，セルと検出器との間に円筒型の 鏡を設置することで散乱光の効率的な集光が可能であり， 吸光度にして 1 程度 $A_{\mathrm{R}}$ の值を下げることが可能であっ た ${ }^{11)}$. また光ファイバーの使用もこの目的には効果的であ った。

\section{$2 \cdot 3$ SPS の高感度化のための条件}

濃度 $C_{0}$ の目的成分を含む体積 $V \mathrm{~cm}^{3}$ の試料溶液から， $m \mathrm{~g}$ の固相（1 $\mathrm{g}$ 当たりの膨潤体積を $v \mathrm{~cm}^{3}$ とする）に濃 縮した際に観測される $A_{\mathrm{RC}}$ は次の式で与えられる。

$$
A_{\mathrm{RC}}=\frac{V}{m v} \frac{1}{1+1 / m D} C_{0} \bar{\varepsilon} \bar{l}=\frac{V}{m v} C_{0} \bar{\varepsilon} \bar{l}
$$

ここで $\bar{\varepsilon}\left(\mathrm{mol}^{-1} \mathrm{dm}^{3} \mathrm{~cm}^{-1}\right)$ は目的成分の固相でのモル 吸光係数, $\bar{l}(\mathrm{~cm})$ は固相を通過する光の実際の平均光路 長，そして $D\left(\mathrm{~cm}^{3} \mathrm{~g}^{-1}\right)$ は目的成分の固相と溶液相に対 する分配比である。 $D$ が非常に大きい場合には，式 ( 2 ) は右端の式のように簡略化できる。式 ( 2) より，溶液法 よりも高い感度を得るためには， $\bar{\varepsilon}$ の大きな系を選ぶか $\bar{l}$ を長くする以外に， D が大きな系では溶液と固相の体積 比 $V / m$ を大きくとることが効果的となることが分かる。 ここで， $m$ を小さくとることに関しては，アクリル製の スペーサーを通常の角型セルに挿入して，光路以外に固相 ができるだけ存在しないようにする工夫を行い，固相を $0.2 \mathrm{~cm}^{3}$ 程度までは小さくすることができた ${ }^{12)}$.

l゙大きくすることは高感度化に有効である。ただし， そのような場合，散乱による減光が著しく，光量確保が問 題となる。しかし，層の厚みを増したときの散乱による減 光度の増加は緩やかで，セル長の対数值とバックグラウン ド減光度との間には直線関係が成立する $(\text { Fig. 1 })^{11)}$ 。市 販のダブルビーム分光光度計では，七ル長 $5 \mathrm{~mm}$ までは十 分定量に用いることができた。

\section{$2 \cdot 4 \quad$ FI-SPS のためのフローセルの開発}

$m$ を小さくするための別の方法として，フローセルを 用いることが挙げられる．Fig. 2 は，入射光がフローセル 中の光路以外は通過しない市販のマイクロブラックフロー セルに，固相の流出を防ぐために，光路部の後ろに多孔性 フィルターを詰めたものである。試料溶液中の目的成分は フローセル内に充填された粒子層の先端部分から濃縮さ れ，粒子層の中を溶液の流れに従って移動していくので， 一番強く着色した固相の先端部分が必ず光路部にくるよう 


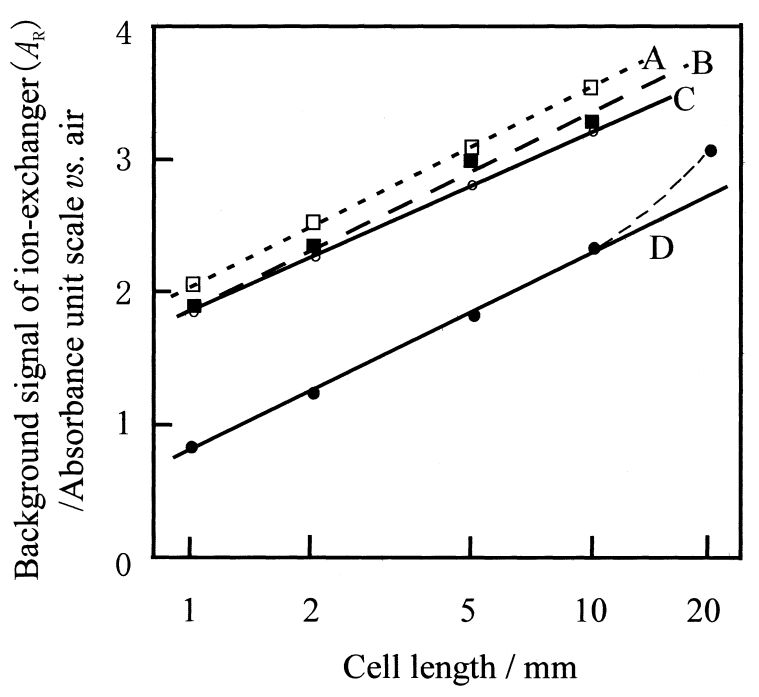

Fig. 1 Cell-length dependence of the ion exchanger background signal $\left(A_{\mathrm{R}}\right)$

A, B : QAE-Sephadex A-25, $\mathrm{Cl}^{-}$form, in $\mathrm{H}_{2} \mathrm{O}$, at 330 $\mathrm{nm}$ (A), and $600 \mathrm{~nm}$ (B); C: Dowex 1-X2, $\mathrm{Cl}^{-}$form (100 200 mesh) in $\mathrm{H}_{2} \mathrm{O}$, at $600 \mathrm{~nm}$; D: AG 50W$\mathrm{X} 2, \mathrm{H}^{+}$form $(100 \sim 200$ mesh $)$ in $\mathrm{H}_{2} \mathrm{O}$, at $550 \mathrm{~nm}$

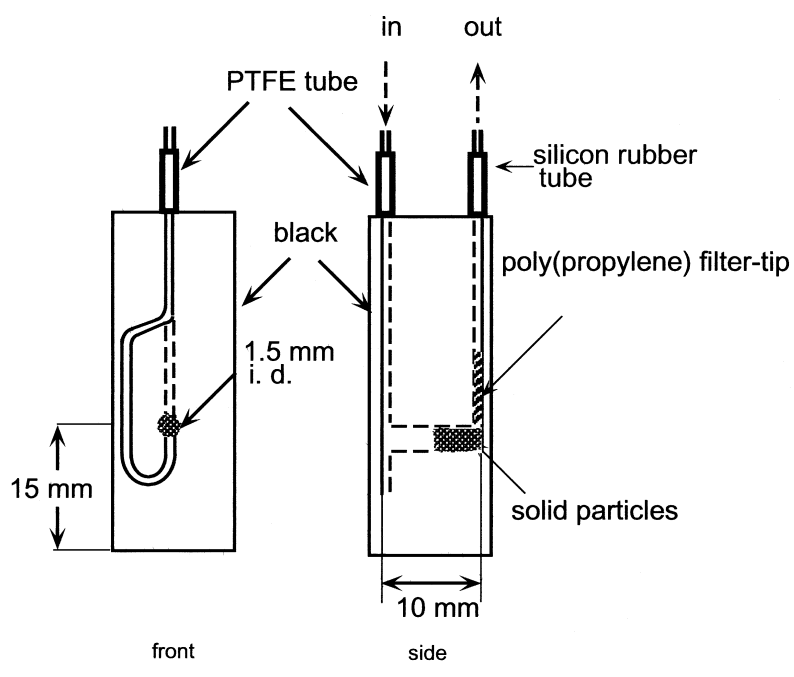

Fig. 2 Flow-through cell for FI-SPS

に粒子を充填して透過光を測定する必要がある。また，よ り少量の試料溶液で高感度化が達成できるように（V/m をより小さな $V$ で大きくできるように), 光路部に充填す る固相体積が小さくてすむタイプのフローセルとして, 光 路部が直径 $1.5 \mathrm{~mm}$ のものを採用した。この場合， $m v$ は $0.02 \mathrm{~cm}^{3}$ 以下にすることができた.

$2 \cdot 6$ において詳しく述べるが， $D$ が十分に大きな系で あれば，固相に吸着した化学種は固相の先端部分に強く吸 着されるため, 1 回の測定に要する分単位の時間内では固 相内での着色帯の移動はほとんど起こらない。しかし， $D$
Table 1 Comparison of sensitivity for copper by FISPS $^{8)}$

\begin{tabular}{cll}
\hline Diameter of cell & $3.0 \mathrm{~mm}$ & $1.5 \mathrm{~mm}$ \\
\hline$S / \mathrm{cm}^{2}$ & 0.0707 & 0.0177 \\
$V / \mathrm{cm}^{3}$ & 4.41 & 4.41 \\
$S R_{\text {calcd }}$ & 62 & 250 \\
$S R_{\text {obsd }}$ & 49 & 220 \\
\hline
\end{tabular}

が $10^{3} \mathrm{~cm}^{3} \mathrm{~g}^{-1}$ 程度であれば，測定の間に着色帯が固相内 を移動し，場合によっては固相から溶出することが考えら れる。したがって $\bar{l} を ， A_{\mathrm{R}}$ の増大により光量不足をきた さない長さである $5 \mathrm{~mm}$ 程度となるように，フローセルの 光路部に充填する粒子の量を調整して使用した ${ }^{8) \sim 10)}$.

$2 \cdot 5$ 固相充填流れセルを用いた場合の感度に関する理

\section{論と実際}

モル吸光係数 $\varepsilon \mathrm{mol}^{-1} \mathrm{dm}^{3} \mathrm{~cm}^{-1}$ の光吸収イオンを含む 溶液 $V \mathrm{~cm}^{3}$ が, 断面積 $S \mathrm{~cm}^{2}$ のフローセルに充填した固 相に定量的に吸着濃縮され, 固相で $\bar{\varepsilon}$ のル吸光係数を示 すとすれば，七ル長 $l \mathrm{~cm}$ での溶液法との感度比 $(S R)$ は,

$$
S R=\bar{\varepsilon} V / \varepsilon S l
$$

で表される ${ }^{5)} . l=1 \mathrm{~cm}, \varepsilon=\bar{\varepsilon}$ の場合,

$$
S R=V / S
$$

となる。この式より, FI-SPS によって得られる感度は, 同じ発色系を用いる溶液法において，試料溶液を $V / S \mathrm{~cm}$ のキャピラリーセルに充填して測定したときに得られる感 度に相当することが分かる.したがって, Table 1 に示す ように, 光路部内径 $1.5 \mathrm{~mm}$ のセルを用いると, 数 $\mathrm{cm}^{3}$ の 溶液の導入で, 溶液法に比べて 100 倍以上の高感度化が 容易に達成できる。また，様々な発色系に関して，実際に 得られる感度と通常の溶液法によるものの比較を行った が，観測值と予測值はほぼ一致した ${ }^{8)}$.

$2 \cdot 6$ 観測される光吸収プロファイルのモデリング（分配 比の目安)

FI-SPS では，試料溶液を流れ系に導入すると，発色し た化学種がフローセル内の固相へ吸着・濃縮される。その 際ベースラインからの吸光度（蛍光法の場合は蛍光強度） の増減が時間とともに観測される (発色曲線)。その一例 として, 流れ系の中に導入された $\mathrm{Cu}(\mathrm{II})$ アクアイオンの 発色曲線を Fig. 3 に示した ${ }^{8)} \cdot \mathrm{Cu}(\mathrm{II})$ イオンが陽イオン交 換樹脂へ吸着・濃縮されるとき, d-d 遷移による光吸収も 


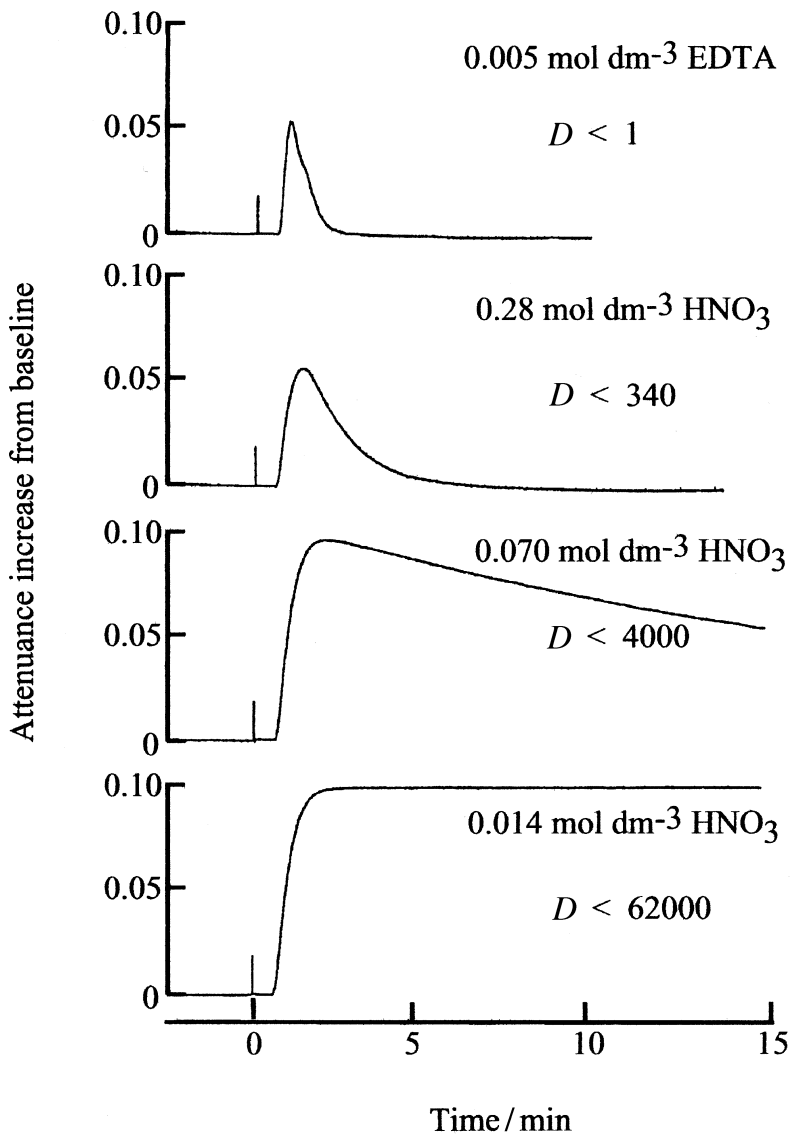

Fig. 3 Color development profiles of hydrated copper(II) for different $D$ system

Sample: $0.17 \mathrm{~cm}^{3}, 15 \mu \mathrm{g}$ of copper(II). The $D$ values under the respective carrier solutions are shown in the Figs. Flow rate: $1.17 \mathrm{~cm}^{3} \mathrm{~min}^{-1}$.

増加する様子が現れている.

異なった酸濃度のキャリヤー溶液を用いることにより， 分配比をいろいろと変化させて測定を行うと, 発色曲線の 形も分配比の大小によって異なるものとなる. 分配比の高 い系では， $0.17 \mathrm{~cm}^{3}$ の試料溶液中のほとんどすべての $\mathrm{Cu}(\mathrm{II})$ イオンが吸着され，20 $\mathrm{cm}^{3}$ 以上のキャリヤー溶液 が通過した後でも銅イオンの脱着は見られない.一方, 分 配比の低い系では, 試料導入後のわずかな時間で銅イオン の脱着が見られる ${ }^{8)}$.

分配比 $D$ の違いによるこのような発色曲線の形の変化 は，フローセル内に充填された固相をカラムとして考える ことで，プレート理論により予測可能であった ${ }^{13)}$.いま, $10000 v \mathrm{~cm}^{3}$ の試料溶液（vは各プレートにおける移動相 の体積; $\mathrm{cm}^{3}$ ) を，0 から 10 までの 11 段のプレートから 構成されるフローセル内のカラムを通過させ，更に $D$ が 変化しないようなキャリヤー溶液を引き続き流すことを考 える. 流れ系に導入する全目的成分の量に対して，フロー セル中に保持される目的成分の分率 $Q$ は次のように示さ

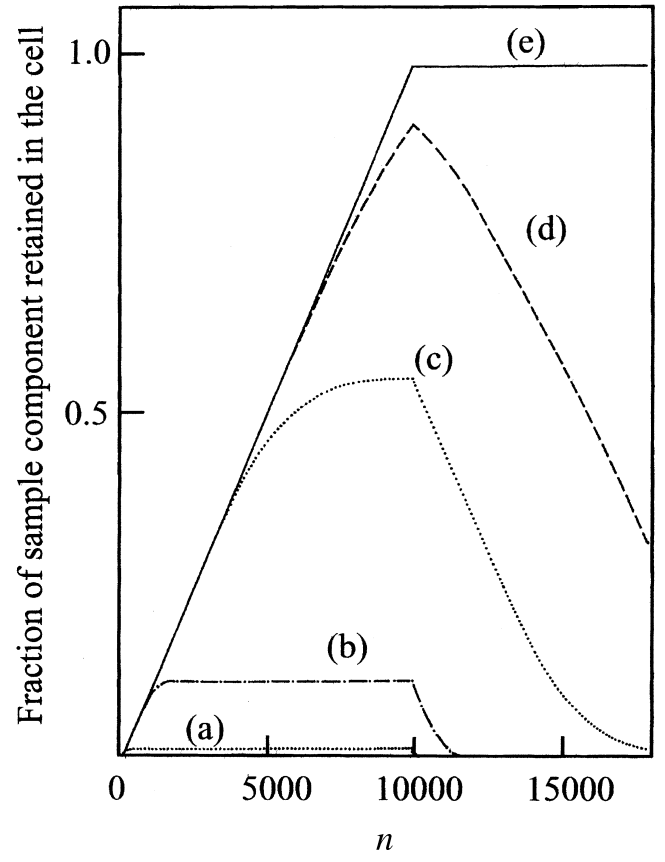

Fig. 4 Retention of components with different $D$ on a solid particle column in the flow-through cell

(a) $D=10$; (b) $D=100$; (c) $D=500$; (d) $D=1000$; (e) $D=10000 \mathrm{~cm}^{3} \mathrm{~g}^{-1}$

れる。

$$
\begin{aligned}
& Q=n / 10000 \quad(n \leq 10) \\
& Q=\frac{1}{10000} \sum_{k=n-9999}^{n} \sum_{p=0}^{10} \frac{k !}{(k-p) ! p !} \frac{(D / i)^{k-p}}{(1+D / i)^{k}} \quad(n \geq 11)
\end{aligned}
$$

ここで， $i$ は固相の間隙に含まれる溶液の体積 $\left(\mathrm{cm}^{3}\right)$ であり, $n$ が 10000 より小さいときは $k=1$ とする. 理論 段相当高さを $0.05 \mathrm{~cm}$ ，カラム断面の直径を $1.5 \mathrm{~mm}$ とす ると, $v$ は $0.3 \mathrm{~mm}^{3}$ となる. 以上のことより，種々の $D$ 值に対し $n$ と $Q$ をプロットすると Fig. 4 が得られる. $D$ が大きい場合には導入された試料溶液中の目的成分のほと んどが吸着されるのに対し，Dが小さい場合（例えば $\left.D=10 \mathrm{~cm}^{3} \mathrm{~g}^{-1}\right)$ には目的成分はほとんど濃縮されないと いう上記の銅イオンで得られた実験結果をよく再現でき た.

同様にして，交換容量に影響を与えないような超微量成 分を流れ系に導入し続けたとき，導入した溶質が固相に 99\%保持される試料導入液量を求めることができる. Table 2 は，上の条件で固相プレートが 10 段及び 20 段あ ると仮定して見積もりを行ったときの, この液量と $D$ と の関係を示したものである。 $D$ が $10^{4} \mathrm{~cm}^{3} \mathrm{~g}^{-1}$ を超える場 合には，数 $\mathrm{cm}^{3}$ の試料中の目的成分をほぼ定量的に濃縮 できることがこの結果より分かる。したがって，溶液法よ 
Table 2 Calculated sample volume ${ }^{\text {a) }}$ in different $D$ system

\begin{tabular}{ccllc}
\hline$D / \mathrm{cm}^{3} \mathrm{~g}^{-1}$ & 10 & 100 & 1000 & 10000 \\
\hline Plate number & & & & \\
11 & 0.006 & 0.057 & 0.57 & 5.6 \\
21 & 0.017 & 0.14 & 1.4 & 14 \\
\hline
\end{tabular}

a) The sample volume $\left(\mathrm{cm}^{3}\right)$ at which $99 \%$ of sample component is retained. Flow-through cell: $1.5 \mathrm{~mm}$ i.d.; 1 plate: $0.05 \mathrm{~cm}$ (mobile phase volume: $0.3 \mathrm{~mm}^{3}$ )

りも 100 倍以上の高感度を得るための目安は, $D$ が $10^{3}$ $\mathrm{cm}^{3} \mathrm{~g}^{-1}$ 以上であることが分かった.

\section{3 応用}

\section{$3 \cdot 1$ 流れ系の設定}

FI-SPS において, 測定操作は, 大別して試料導入，発 色, 吸着・濃縮 (分光測定), 脱着の 4 つのステップから 成る。また，それぞれのステップには種々の方法がとられ ており, 測定される化学種の特性に応じてそのそれぞれを 組み合わせて流れ系全体を設定しなければならない，著者 らがこれまでに報告した FI-SPS の応用例に関して，その 概略（測定波長, 溶液法との感度比, 検出限界等）を Table 3 にまとめて示した. 以下に，これらの詳細につい て実例を交えて紹介する。

$3 \cdot 1 \cdot 1$ 試料導入 通常のフローインジェクション分 析（FIA）法とは異なり, 数 $\mathrm{cm}^{3}$ 程度の試料が測定に用い られる。Dが十分に大きければ，試料のほとんどが濃縮 されるため, 試料を流れ系に導入したときに見られる拡散 や希釈の影響を受けず，導入試料体積に比例する高感度化 が達成される。

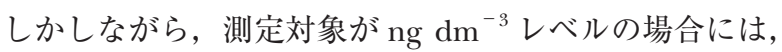
モル吸光係数がいかに大きな系であったとしても（例えば $10^{5} \mathrm{~mol}^{-1} \mathrm{dm}^{3} \mathrm{~cm}^{-1}$ 程度), 数 $\mathrm{cm}^{3}$ 程度の試料溶液では十 分な感度は得られない。このような場合には, 感度向上の ためオンライン濃縮カラムを併用した試料の導入が有効で ある。

高純度水中に含まれる超微量の全鉄濃度を測定するため に, 内部に陽イオン交換樹脂を充填した内径 $2 \mathrm{~mm} \times$ 長さ $50 \mathrm{~mm}$ のポリテトラフルオロエチレン（PTFE）製オンラ インカラムを用いた ${ }^{14)}$. このカラムに試料溶液 $80 \mathrm{~cm}^{3}$ 中 に含まれる鉄イオンを濃縮し, キャリヤー(酢酸緩衝溶液) によりオンラインでこれらを脱着した。更に 4,7-diphenyl1,10-phenanthroline-disulfonate（DPPS）+ヒドロキシルア ミンのラインと混合し, 呈色錯体をフローセル中の陰イオ ン交換体に濃縮しながら定量することで, $10 \mathrm{ng} \mathrm{dm}^{-3} レ$ ベルの鉄を検出可能とした.

オンラインカラムによる試料導入は高感度化を図れるだ
けでなく，もともと選択性のあまり高くない試薬を用いた 際の選択性の向上や，妨害成分の除去に対しても有効であ る.試料溶液中の Bi をライン内で Bi-ヨード錯体とし, こ れをフローセル内の陰イオン交換体に吸着濃縮させて超微 量の $\mathrm{Bi}$ の定量を行った ${ }^{9)}$ 。この際，陰イオン交換樹脂を充 填したオンラインカラムに試料溶液中の Bi をクロロ錯体 として前濃縮することで, 大過剩存在すると正誤差を与え る $\mathrm{Pb}$ と $\mathrm{Sb}$ の影響を除去することに成功した。また， Sephadex ゲルによる試料の前処理とオンライン脱着とを 組み合わせた Mo(VI) の定量法も報告した. Mo(VI) を選 択的に吸着濃縮させた Sephadex ゲルカラムをエチレンジ アミン四酢酸（EDTA）水溶液のラインの中に組み込んで, $\mathrm{Mo}(\mathrm{VI})$ を EDTA 錯体として脱着させた後, ライン内で夕 イロンと発色させ，フローセル中の QAE-Sephadex A-25 (Pharmacia, Uppsala) に濃縮して定量を行った。この前 処理により $\mathrm{Cr}(\mathrm{VI}), \mathrm{Ti}(\mathrm{IV}), \mathrm{U}(\mathrm{VI}), \mathrm{V}(\mathrm{V})$, 海水中の高濃 度 $\mathrm{NaCl}$ 等の影響が除去可能であった ${ }^{15)}$.

$3 \cdot 1 \cdot 2$ 発色試料溶液中の目的成分を有機試薬によ り発色させる方法には，1）通常の FIA と同様に試料と発 色試薬とをライン内で混合して発色させる，2）あらかじ めフローセル内の固相に発色試薬を固定化しておき, 試料 溶液を通過させることにより発色させる，3）試料溶液中 の目的成分のみを固相に吸着させ, その後発色試薬を流 す，の 3 通りの方法がある。1）の方法は, 発色試薬が測 定波長に吸収を持たない場合や，固相に吸着されない場合 には有効である．前述の $\mathrm{Bi}$ の系では KI を発色試薬に用い るが，Bi-ヨード錯体の測定波長である $472 \mathrm{~nm}$ に KI は吸 収を持たないため，これを連続的に送液することが可能で ある ${ }^{9)}$. 2) の方法は発色試薬を固相に対し化学的に修飾 可能な場合や, 発色試薬の固相に対する分配比が非常に大 きく，測定の 1 サイクルの間に固相からの脱着が起きな いような場合に用いる.キシレノールオレンジ（XO）が 陰イオン交換樹脂に対し非常に強く吸着されることを利用 して，フローセル内に充填した陰イオン交換樹脂を，1,2ジアミノシクロヘキサン四酢酸（CyDTA）共存下，キレ 一ト樹脂のように用いることで, 海水中や天然水中に存在 するV の定量も行っている ${ }^{16)}$. 3) の方法は試薬の選択性 が高くなくても固相が試料中の目的成分に対し高い選択性 を示す場合に有効である.

本法では sub- $\mu \mathrm{g} \mathrm{dm}^{-3}$ 程度の濃度レベルの成分分析が中 心となるが，このような場合では，送液に使用するポンプ ヘッドやバルブ類, 周囲の䨌囲気からの污染が大きな問題 となる．特に $\mathrm{Fe}$ や $\mathrm{Al}$ のような污染を受けやすい成分の定 量の際には，1）の方法のように発色試薬を継続的に送液 したのでは, 污染された試薬類から供給される目的成分が 固相へ濃縮されることにより，ベースラインは時間ととも に徐々に上昇していくのが観測される．污染の影響を受け 
Table 3 Summary of FI-SPS

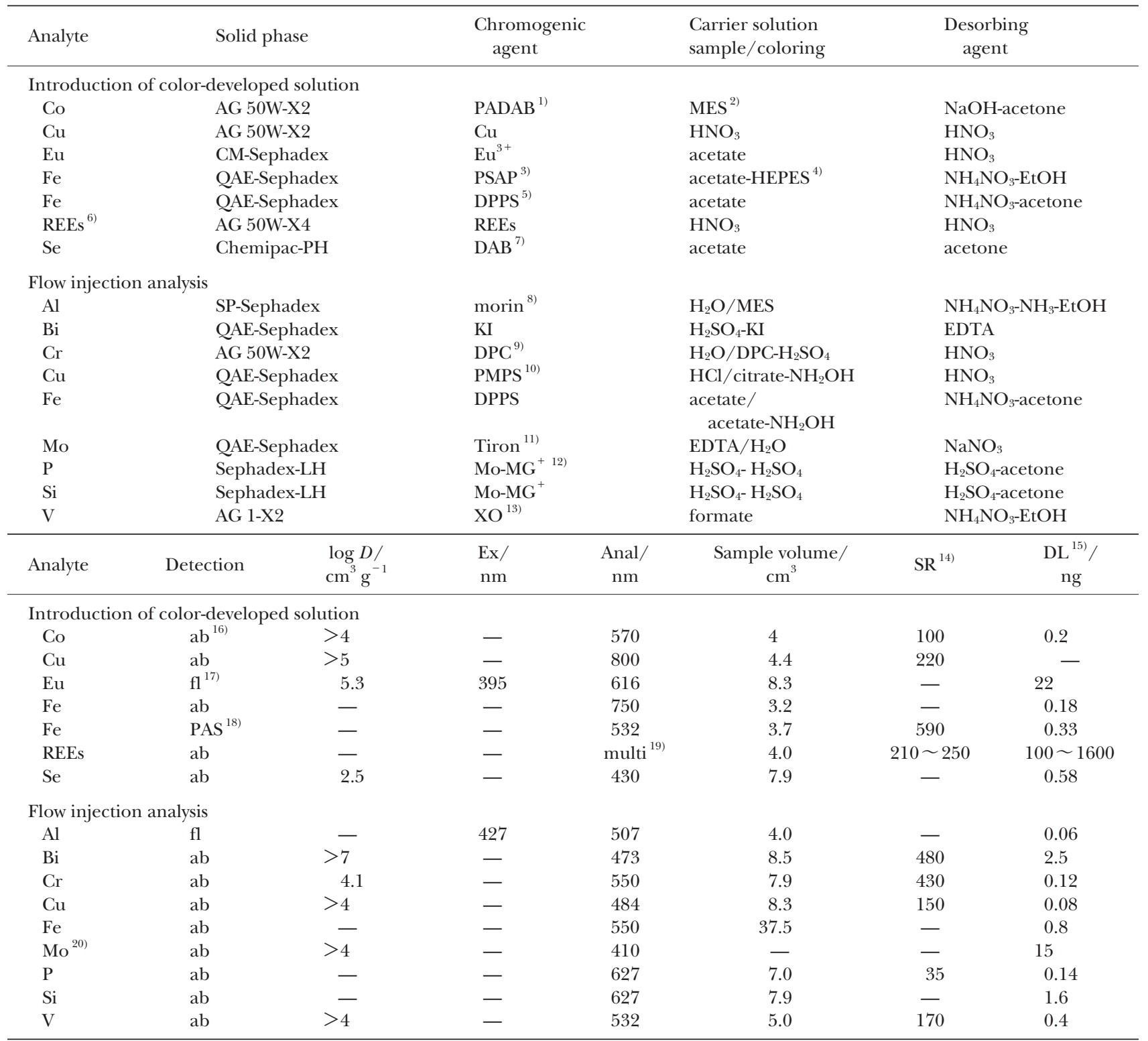

1) PADAB : 2-(5-bromo-2-pyridylazo)-5-diethylaminophenol; 2) MES : 2-( $N$-morpholino) ethanesulfonic acid; 3) PSAP: 2-nitroso-5$\{N$-n-propyl- $N$-(3-sulphopropyl)amino\}phenol; 4) HEPES : 2-\{4-(2-hydroxyethyl)-1-piperazinyl\}ethanesulfonic acid); 5) DPPS : 4,7diphenyl-1,10 phenanthroline-disulfonate; 6) REEs: Dy, Ho, Tm, Er, Nd; 7) DAB: 3,3'-diaminobenzidine; 8) morin: 2',3,4',5,7-pentahydroxyflavone; 9) DPC: 1,5-diphenylcarbazide; 10) PMPS: 4,7-diphenyl-2,9-dimethyl-1,10-phenanthrorindisulfonate; 11) Tiron: 1,2-dihydroxybenzene-3,5-disulfonic acid; 12) $\mathrm{MG}^{+}$: Malachite Green; 13) XO : xylenole orange; 14) $l=1 \mathrm{~cm}$; 15): Detection limit which is in terms of the amount of these metal ions adsorbed in the solid phase packed in the cell was evaluated according to the IUPAC rule $(3 \sigma) ; 16)$ : Absorptiometry; 17): Fluorometry; 18): Photoacoustic spectroscopy; 19): Multi components analysis; 20): Preconcentrated samples were used.

ない場合でも，フリーの発色試薬が固相に濃縮されかつ測 定波長において試薬自身が吸収を持つ場合も同様である。 このような場合には，以下に幾つか例を挙げるとおり，マ ージングゾーン法が有効である。例えばモリブドリン酸と マラカイトグリーンのイオン対を用いた超微量ケイ酸 ${ }^{13)}$, リン酸 ${ }^{17)}$ の定量では, 試料溶液とモリブデン酸+マラカイ トグリーンの混合溶液を酸性下で混合させ，生成したイオ ン対を Shephadex LH ゲル（Pharmacia, Uppsala）に濃縮 して定量を行ったが，フリーのマラカイトグリーンが固相
に強く吸着され，また測定波長の $627 \mathrm{~nm}$ で強い吸収を持 つため，マージングゾーン法により定量を行わなければな らかった。また，2',3,4',5,7-pentahydroxyflavone（モリン） を用いた超微量 $\mathrm{Al}$ の蛍光定量では, 弱酸性下, ライン内で 生成した Al-モリン錯体を陽イオン交換体 SP-ShephadexC25 （Pharmacia, Uppsala）に濃縮して定量を行ったが，周 囲の環境から混入したと思われる $\mathrm{Al}$ が錯体を生成して固 相に濃縮されるため，フリーのモリンは陽イオン交換体に は吸着されないにもかかわらず，マージングゾーン法を用 
いて定量を行わなければならなかった ${ }^{18)}$.

$3 \cdot 1 \cdot 3$ 固相の種類 イオン交換体をはじめ, 吸着濃 縮の媒体としては多くのものが用いられているが, その選 択は定量に用いる有機試薬や定量する目的化学種の性質に 依存する。

電荷を持った化学種の濃縮媒体としては, ポリスチレン を架橋したイオン交換樹脂やデキストランを架橋したイオ ン交換体が用いられた。芳香族環を持つ化学種の吸着濃縮 に関しては，Dowex 等のイオン交換樹脂を用いるが，こ れは, 静電的相互作用のほかに, 目的化学種の持つ芳香族 環とイオン交換樹脂の骨格（特にベンゼン環に）間の強い （疎水的）相互作用が働くため，イオン交換樹脂のほうが イオン交換体デキストランよりもこれらの化学種に対し高 い分配比を示すためである。しかしながら，イオン交換樹 脂は，ベンゼン環による非常に大きな吸収のため，450 $\mathrm{nm}$ 当たりから短波長側では急激に吸収バックグラウンド が増加する。したがって，目的成分の吸収極大が $450 \mathrm{~nm}$ 以下にある場合や蛍光測定の際には，ベンゼン環を持たな いSephadex をはじめとするイオン交換体デキストランを 通常用いる.

試料溶液中の $\operatorname{Cr}(\mathrm{VI})$ がジフェニルカルバジド（DPC） と反応してライン内で生成した錯体を，フローセル内の陽 イオン交換樹脂に吸着濃縮させる sub- $\mu \mathrm{g} \mathrm{dm}{ }^{-3}$ レベルの $\mathrm{Cr}(\mathrm{VI})$ の定量法を開発した。その際の濃縮媒体にDowex $50 \mathrm{~W}-\mathrm{X} 2$ 陽イオン交換樹脂を用いた理由は，錯体の極大吸 収波長が $550 \mathrm{~nm}$ にあるため，吸収バックグラウンドの影 響を受けることなく高い $D$ が期待できたからである ${ }^{10)}$.

一方, 電荷を持たない化学種の濃縮には Shephadex LH ゲル（Sephadex ゲルのヘキサプロピル誘導体）や，シリ カゲル，ガラスビーズに $\mathrm{C}_{18}$ 化合物を修飾したものが用い られる。これらはもちろん疎水性相互作用を利用した吸着 （固相抽出）であるから，吸着濃縮させる化学種の極性に あった固相を選択しなければならないのはもちろんであ る。しかしながら，低極性の固相には，一部透光性の悪い ものがあるので注意を要する，前述のケイ酸，リン酸の例 では，モリブドリン酸（ケイ酸）-マラカイトグリーンの イオン対を Shephadex LH ゲルに抽出したが，それ以外 にも，酸性領域でバッチ発色させた Se(IV) と 3,3'diaminobenzidine (DAB) との錯体（ピアズセレノール） を, pH 6 でフローセル中に充填した Chemipack-PH に吸 着濃縮し，FI-SPS により微量 Se(IV) を定量することもで きる。

FI-SPS では，フローセル内の固相に吸着濃縮された目 的成分の脱着の操作が必要となる。ところが吸着媒体にイ オン交換樹脂を用いると，目的化学種（有機錯体）と樹脂 骨格との相互作用が強すぎて，目的成分の脱着が難しいよ うな場合がしばしば見られる。このような場合にはデキス
トラン骨格のイオン交換ゲルが用いられる．銅を含む試料 溶液と，銅に対して高い選択性を持つ 4,7-diphenyl-2,9dimethyl-1,10-phenanthrorindisulfonate (PMPS) +ヒドロ キシルアミンとをライン内で混合発色させ，生成した $\mathrm{Cu}(\mathrm{I})$-PMPS 錯体をフローセル中の陰イオン交換体 QAESephadex A-25 に濃縮することができる。この性質を利用 して $0.1 〜 10 \mu \mathrm{g} \mathrm{dm}^{-3}$ レベルの銅の定量法を開発した ${ }^{19}$. その際に, $\mathrm{Cu}(\mathrm{I})$-PMPS 錯体の極大吸収波長が $484 \mathrm{~nm}$ で あり，しかも陰イオン交換樹脂に対して非常に大きな分配 比を示すにもかかわらず，濃縮媒体に陰イオン交換ゲルを 用いたのはこの理由からである。

$\mathbf{3} \cdot \mathbf{1} \cdot \mathbf{4}$ 脱着連続分析を行うために，一度固相に濃 縮された試料成分の脱着の過程が必要となることが，本法 が通常の流れ分析法と大きく異なる点である．吸着化学種 の固相からの脱着骫としては次のようなものがある.

1）吸着媒体がイオン交換体の場合には，目的成分の吸 着がイオン交換によるので， $D$ は外部電解質濃度が増加 するに従って減少する。したがって $1 \mathrm{~mol} \mathrm{dm}^{-3}$ 程度の酸 や 2〜 $4 \mathrm{~mol} \mathrm{dm}$ 程度の塩溶液を用いた. 架橋デキスト ランからなるイオン交換体を用いる場合には，耐薬品性の 問題から酸やアルカリの濃度をあまり高くしないよう注意 を要する。

2）固相に発色試薬が固定化されている場合や，発色試 薬が測定波長において吸収を持たない場合には，EDTA 等 の錯形成剂を用いて呈色錯体を分解し，試薬を脱着するこ となく目的成分のみを脱着することが可能であった。この 目的のためには $10^{-2} \sim 10^{-3} \mathrm{~mol} \mathrm{dm} \mathrm{dm}^{-3}$ の錯形成剂を用い た。また，低濃度の酸やアルカリにより，pH を錯生成に 関する至適条件からずらすことで，呈色錯体を分解するこ とも行われている.

3）電荷を持たない化学種が疎水的な相互作用により吸 着しているような場合には，この相互作用を弱めるために アセトンやエタノールのような水溶性有機溶媒の使用が効 果的であった。しかしながら，それらを水と混合せずに用 いれば，ライン内で気泡が発生しやすくなり，これがセル 内の固相を充填した部分にたまれば，光の透過性に大きく 影響する。したがって，50\%（w/w）程度を目安に水と混 合した溶液を用いることが適当である。

4）前項で述べたように，目的成分が静電的相互作用だ けでなく，疎水性相互作用の寄与もあるため非常に強く吸 着している場合には，双方の相互作用を弱めるために2 $4 \mathrm{~mol} \mathrm{dm}{ }^{-3}$ の塩溶液と水溶性有機溶媒を等量混合したも のを用いた。

脱着剂は，通常 1 回の試料測定が終わる度に脱着剤用 の六方バルブを切り替えてラインに導入されるが，目的成

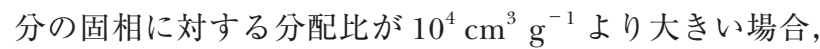
例えば前述の Bi-ヨード錯体や Cr (VI)-DPC 錯体などの場 


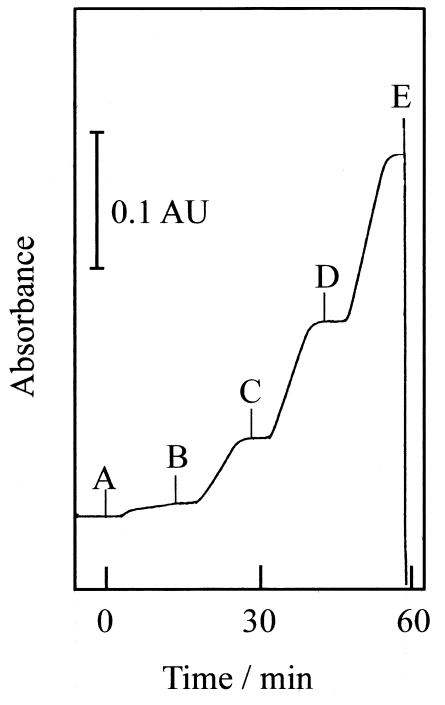

Fig. 5 Color development profile of $\mathrm{Cr}(\mathrm{VI})-\mathrm{DPC}$ complex obtained by FI-SPS

Sample volume: $7.9 \mathrm{~cm}^{3}$; A: blank; B : 0.2 ; C: 0.4 ; D : $0.6 \mu \mathrm{g} \mathrm{dm}^{-3}$ of $\mathrm{Cr}(\mathrm{VI})$ and $\mathrm{E}$ : desorbing agent solution

合では, 1 回の測定ごとの脱着は必要なく, 数サンプルの 測定の後脱着を行うことが可能である (Fig. 5 $)^{9) 10)}$.

脱着剂導入の操作を簡略化するために，試料のキャリヤ 一と脱着剂とを兼用する方法も行われている ${ }^{20)}$. この方法 では，六方バルブを用いて脱着剤のラインの中に試料溶液 を挿入する. サンプルゾーンがセルを通過して固相への目 的成分の吸着（透過光測定）が終わったら, サンプルゾー ンの前後を挟んでいる脱着剤によって, 引き続き吸着化学 種が脱着される仕組みである。この方法では脱着剤用の六 方バルブやその切り替え作業などが不要になるが, 試料溶 液と脱着剂の塩組成が大きく異なるため, サンプルゾーン の前後で固相の散乱バックグラウンドの変動は避けられな w.

\section{4 固相分光流れ分析法の他の応用例}

\section{$4 \cdot 1$ 蛍光光度法への応用}

固相に濃縮した化学種に励起光を照射した場合, 発せら れる蛍光強度と目的成分濃度との関係は, 吸光光度法の場 合と類似して，以下の式で表すことができる ${ }^{21)}$.

$$
F=k I_{0} \frac{V}{m v} \frac{1}{1+1 / m D} C_{0} \bar{\phi} \bar{\varepsilon} \bar{l}=k I_{0} \frac{V}{m v} C_{0} \bar{\phi} \bar{\varepsilon} \bar{l}
$$

ここで $F$ は蛍光強度, $k$ は定数, $I_{0}$ は入射光強度, $\bar{\phi}$ は 固相内での蛍光化学種の蛍光量子収率である. 高い感度を 得るために励起光の強度を大きくすることは, 固相法には 適さない. 励起光と直交する方向の蛍光を測定しても, 励

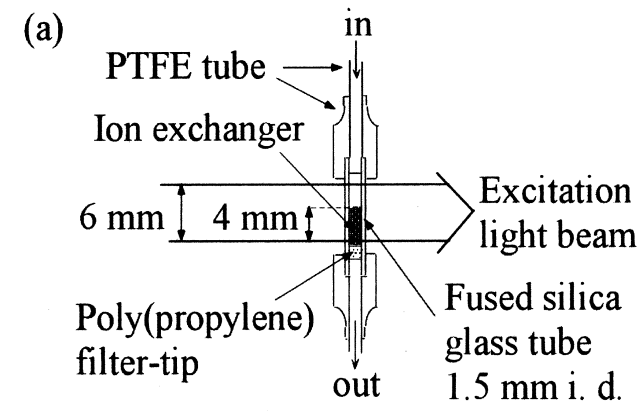

(b)

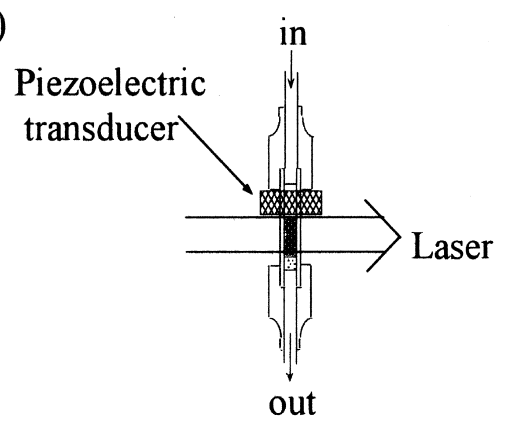

Fig. 6 Flow-through cell packed with solid particles (a) for spectrofluorometry; (b) for PAS

起光の散乱反射光が大きなバックグラウンドをもたらすか らである．高感度化のためには，むしろ目的成分の微少量 固相への濃縮効率をできる限り大きくすることが肝要であ る.この目的に用いたセルを Fig. 6 (a) に示す. 内径 1.5 $\mathrm{mm} \phi$ の石英管に固相の流失を防ぐためのポリプロピレン 製フィルターを挿入したものである. 石英管と PTFE チュ ーブの接続には熱収縮性のPTFE チューブを使用してい る.

吸光光度法の場合と同様に, 目的化学種は固相の先端部 分から濃縮され，Dが大きければ先端付近から最も強い 蛍光が発せられる。 $D$ がさほど大きくなければ，吸着化 学種は固相の中を溶液が流れる方向（この場合では下向 き）に移動していく。したがって，できるだけ高感度に蛍 光測定を行うためには, 先端部分を含め, 蛍光化学種が吸 着している部分すべてに励起光が照射されなければならな い. 著者らの用いた測光装置では，励起光の幅が約 $6 \mathrm{~mm}$ であったので，フィルターに励起光が当たらないように固 相の高さを $4 \mathrm{~mm}$ に調整して蛍光測定を行った. Fig. 7 に $\mathrm{Eu}$ の蛍光光度定量の際に観測された発色曲線を示した ${ }^{21)}$. $\mathrm{Eu}$ 以外にも $\mathrm{Tb}$, Dy 等の希土類元素の発する蛍光は, 弱 酸性陽イオン交換体であるCM-Sephadex（Pharmacia, Uppsala）に吸着・濃縮させるだけで増強される.この現 象を利用して, 蛍光試薬を用いなくても $8 \mathrm{~cm}^{3}$ 程度の試料 溶液を用いるだけで $5 〜 50 \mu \mathrm{g} \mathrm{dm}{ }^{-3}$ レベルのこれら希土 類元素の定量が可能であった. 


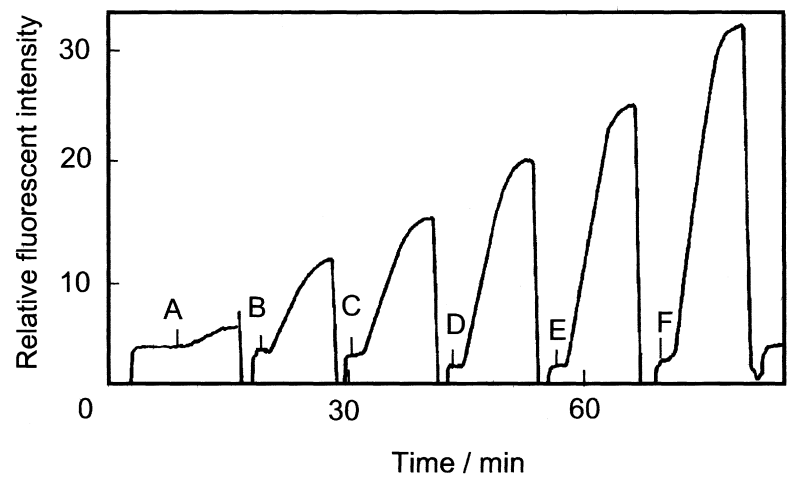

Fig. 7 Fluorescence development profiles of europium obtained using FI-SPS A: $0 ; \mathrm{B}: 10 ; \mathrm{C}: 20 ; \mathrm{D}: 30 ; \mathrm{E}: 40 ; \mathrm{F}: 50 \mu \mathrm{g} \mathrm{\textrm {dm } ^ { - 3 }}$ europium; Sample volume: $8.3 \mathrm{~cm}^{3}$

\section{$4 \cdot 2$ 光音響測定への応用}

固相光音響法も FI-SPS に応用可能である ${ }^{22)}$. 固相光音 響の測定には，Fig. 6（b）のセルに筒状の圧電素子を取 り付けて測定を行った。 あらかじめバッチ法により生成さ せた Fe(II)-DPPS 錯体を酢酸緩衝溶液の単一流路系に導入 し，フローセル中の陰イオン交換体 QAE-Sephadex に濃 縮させ，その際観測される PAS 時間分解シグナルの変動 を観測した。フローセルから固相を除いた場合（溶液法） と比較して $4 \mathrm{~cm}^{3}$ の試料溶液を用いるだけで 590 倍高感度 であることが確認できた。

\section{$4 \cdot 3$ マルチチャンネル検出器を用いた多元素同時定量}

FI-SPS は, 試料溶液中の目的成分のフローセル中での 濃縮過程を含むことから, 通常 1 試料の測定に $10 \sim 20$ 分 程度の時間を要し, 多数の試料のルーティン分析には適用 が難しいという問題点があった。しかし，イオンクロマト グラフィーのように，1 回の測定で複数の成分を同時に定 量することができるようになれば，1 目的成分当たりの測 定時間の短縮が図れるため, 新たなはん用性を与え得るこ とが期待できる，そこで，これまで単一成分に対してのみ 適用してきた FI-SPS を, 多成分同時定量に適用すること を試みた。

$\mathbf{4} \cdot \mathbf{3} \cdot \mathbf{1}$ 測光装置 測光装置の概略を Fig. 8 に示し た. 固相減光度の検出には, 入射部と受光部に光ファイバ ーを装着したマルチチャンネル検出器（大塚電子製 MCPD-2000 型, 又は 3000 型）を, 光源には高輝度の $\mathrm{I}_{2}$ ランプを用いた，光ファイバーを用いることで，使用する セルの形状に合わせて自由に光学系を設定することがで き, 固相による散乱光の効果的な集光により $A_{\mathrm{R}}$ を低減さ せることが可能であった. 更に, 高輝度のハロゲンランプ を光源に用いることで十分な光量が確保され, 通常の分光 光度計では測定し得ないような, $A_{\mathrm{R}}$ と吸着化学種による

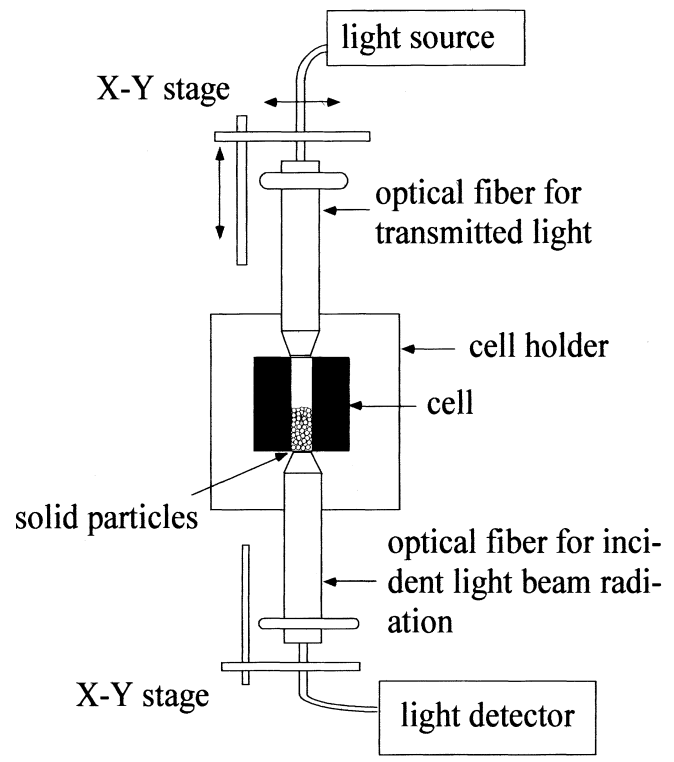

Fig. 8 Schematic diagram for the light measurement system for multi-elements FI-SPS

正味の吸収の和が 4 を超える領域においても Beer 則が成 立することを確認している ${ }^{23)}$.

$4 \cdot 3 \cdot 2$ 応用 測光系の最適化に関する基礎データの 収集を行うため, 発色試薬を用いない 5 種類の希土類元 素（Dy，Ho，Tm， Er，Nd）の単純混合系を用いて，同 時定量の可能性について検討した ${ }^{24)}$. 希土類元素の混合溶 液を単一流路系に導入し，フローセル中に充填した陽イオ ン交換樹脂（Muromac 50W-X4）に吸着・濃縮させる. 各 希土類元素は複数の波長に d-f もしくは f-f 遷移に伴う固 有の吸収ピークを持つが，他成分からの寄与が最も少ない 波長を選択し, 吸着に伴う吸光度の増加をモニターするこ とで，これら 5 成分の同時定量を行った。その結果，わ ずか $4 \mathrm{~cm}^{3}$ の試料溶液を用いるだけで, 発色試薬を用いな くともおよそ 5 分に 1 サンプルの割合で, $10^{-6} \mathrm{~mol} \mathrm{dm}{ }^{-3}$ レベルの希土類元素の定量が可能であった.

ライン内で生じる圧力変動や, 脱着剤導入時に電解質濃 度の変化が起こると, 固相の膨潤・収縮が起きる.これが 原因で， $A_{\mathrm{R}}$ の変動とそれに起因するバックグラウンドノ イズがしばしば観測される。この $A_{\mathrm{R}}$ の変動には波長依存 性がないため, 目的成分の測定波長と, 吸収のない波長の 二波長の吸光度差を連続的に観測することで，バックグラ ウンドノイズの相殺が可能となる.

各希土類元素の測定波長は, 他の希土類成分の寄与が最 も少ないものを選んでいるが，それでも他成分濃度のほう が相対的にかなり高くなればその寄与は無視できない.ま た，発色試薬を用いて複数成分の同時分析を行うような場 合では, 多くの場合吸収帯の重なりが問題となる。このよ うな場合でも, 通常の溶液法と同様に, 複数波長で測定し 


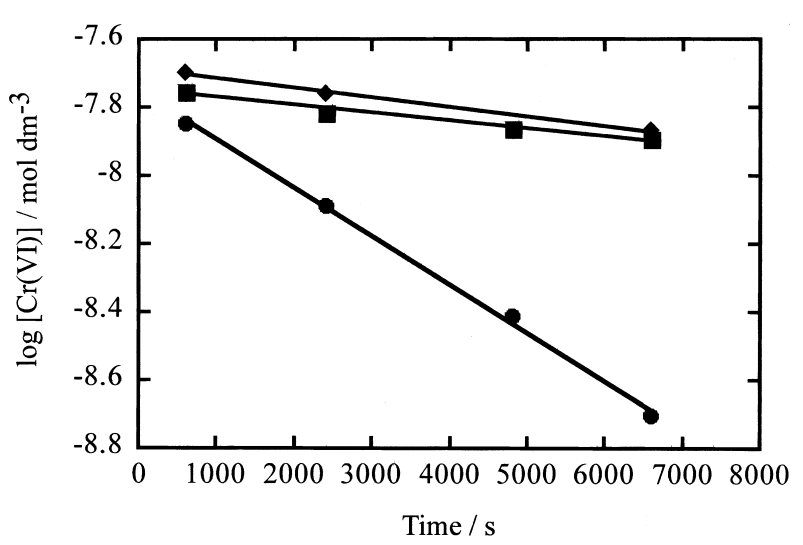

Fig. 9 Time dependence of $\mathrm{Cr}(\mathrm{VI})$ reduction in natural waters at $25^{\circ} \mathrm{C}$

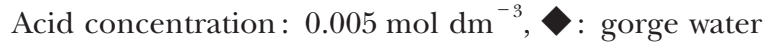
from Sefuri (Fukuoka); $\mathbf{\square}$ : river water from Muromi (Fukuoka); : lake water from Sakata (Niigata)

た吸光度の算術的な処理（多変量解析など）を行えば，分 別定量が可能であることが確認できた.

\section{$\mathbf{4} \cdot \mathbf{4}$ 超微量成分のスペシエーション（状態別定量）}

なんらかの前分離法を適用すれば，誘導結合プラズマ （ICP） 発光分光法や ICP-質量分析法（MS）でもスペシエ ーションは可能である. しかし, 前分離の過程が複雑にな れば，それだけ溶存化学種の状態変化が起きる可能性が高 くなる，FI-SPS には，高感度な分析が容易に行えるとい うだけではなく, 適切な発色系を選択すれば前分離なしに 超微量成分のスペシエーションも可能という利点もある. この点を最大限生かすべく, 本法を用いた天然水中の溶在 超微量 $\mathrm{Cr}$ の酸化状態別定量も提唱している ${ }^{27)}$. この方法 では，試料溶液中の $\mathrm{Cr}(\mathrm{VI})$ とジフェニルカルバジドをラ イン内で混合し, 生成した有色錯体をフローセル内の陽イ オン交換樹脂に吸着濃縮させることで, sub- $\mu \mathrm{g} \mathrm{dm}{ }^{-3} レ$ レ ルの $\mathrm{Cr}(\mathrm{VI})$ の定量を行う. 酸化剂として試料に添加する ペルオキソ二硫酸の有無により, 総クロム, $\operatorname{Cr}(\mathrm{VI})$ の定 量を行い，その差より $\mathrm{Cr}$ の酸化状態別量を決定した.

天然水中の溶存クロムの酸化状態別分析を行う場合, 試 料保存の酸固定は行わない. 添加した酸により $\operatorname{Cr}(\mathrm{VI})$ の 酸化還元電位が高まり, 共存する有機物を酸化すること で, $\mathrm{Cr}(\mathrm{VI})$ の $\mathrm{Cr}(\mathrm{III})$ への還元が進行しやすくなるからで ある. 著者らはこの還元反応を定量的に取り扱うために, 種々の天然水中の溶存 $\operatorname{Cr}(\mathrm{VI})$ の還元速度を異なる条件下 で追跡した ${ }^{26)}$ 。採取地点において沪過した試料は PTFE 容 器に保存して持ち帰り, 測定開始直前に既知量の硫酸を添 加した. 酸を添加した試料の $7.9 \mathrm{~cm}^{3}$ を, 一定時間ごとに 流れ系に導入することで, 還元反応の進行による $\mathrm{Cr}(\mathrm{VI})$ 濃度の減少を経時的に測定した。試料には溶存有機物濃度
の異なる複数のものを用いたが，いずれの場合も酸添加直 後から $\mathrm{Cr}(\mathrm{VI})$ 濃度の減少が見られた.この還元反応は,

$$
\begin{aligned}
& -d[\mathrm{Cr}(\mathrm{VI})] / d t \\
& =k[\mathrm{Cr}(\mathrm{VI})][\text { 溶存有機物 }]\left[\mathrm{H}^{+}\right]^{\mathrm{n}}
\end{aligned}
$$

の速度式により進行すると考えられるが, 溶存 $\operatorname{Cr}(\mathrm{VI})$ 濃 度 $\left(10^{-8} \mathrm{~mol} \mathrm{dm}{ }^{-3}\right.$ 以下) に比べ溶存有機物濃度はかなり 高いため, 酸濃度一定の条件下では事実上擬一次反応で進 行することが確認された（Fig. 9). また，その際の速度

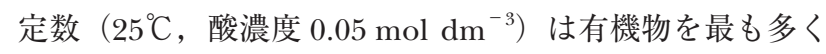
含む水の $3.27 \times 10^{-4}$ から最も低い水の $5.27 \times 10^{-5}\left(\mathrm{~s}^{-1}\right)$ まで分布し，酸濃度を $1 / 10$ にすると速度定数も減少する ことが確認できた。 上記 $\mathrm{Cr}$ 分析法は, 天然水中に存在す る超微量 $\mathrm{Cr}$ の酸化状態別定量に対し非常に有効であるだ けでなく, 天然水中に溶存する $\mathrm{Cr}$ の酸化還元反応の定量 的追跡に最適であることが明らかとなった。

数種の遷移金属元素に対し，それぞれ異なった波長に吸 収極大を持つ錯体を生成するニトロソアミノフェノール誘 導体 Nitroso-PSAP を発色試薬として用いことで, sub- $\mu \mathrm{g}$ $\mathrm{dm}^{-3}$ レベルの $\mathrm{Fe}(\mathrm{II}, \mathrm{III}), \mathrm{Co}(\mathrm{II})$ を同時に定量する酸化状 態別定量法も提唱している. 赤色の Fe (III)-PSAP 錯体が フローセル中の陰イオン交換体に吸着濃縮されると, 中性 以上では容易に還元され緑色の Fe(II)-PSAP 錯体となる が, pH 5.0 以下ではこの反応は全く進行しない。一方， Co(II)-PSAP 錯生成反応は pH に大きく依存しないため, 還元剤を用いなくても単にキャリヤーの $\mathrm{pH}$ を変えるのみ で $\mathrm{Co}(\mathrm{II})$ と $\mathrm{Fe}(\mathrm{II}),(\mathrm{III})$ の酸化状態別定量を容易に行う ことを可能にした。錯生成の際の $\mathrm{pH}$ を調整することで, 高濃度の亜鉛による妨害も除去でき，高い選択性の下， $3.2 \mathrm{~cm}^{3}$ の試料溶液を用いるだけで Fe(II) で $56, \mathrm{Fe}(\mathrm{III})$ で56, Co で $40 \mathrm{ng} \mathrm{dm}^{-3}$ の検出限界が得られている.

$$
5 \text { おわりに }
$$

ここまで主に FI-SPS の原理や応用に関して述べてきた が，最後に本法の特徴をもう一度まとめておく.

1）本法の検出感度は, 導入する試料液量に比例し，ま たフローセルの光路部の断面積に反比例する。すなわち, 光路部断面積の小さなセルに, ごく少量の固相を充填して 測定を行えば，より少量の試料溶液による高感度化が可能 となる。

2）通常の FIA とは異なり，測定に供される試料のほと んどが濃縮されるため，試料を流れ系に導入したときに見 られる希釈の影響を受けない。

3) 高い分配比 $\left(D>10^{4} \mathrm{~cm}^{3} \mathrm{~g}^{-1}\right)$ と吸光係数 $\left(\varepsilon>10^{4}\right.$ $\left.\mathrm{mol}^{-1} \mathrm{dm}^{3} \mathrm{~cm}^{-1}\right)$ を有する錯生成系に対しては，1 $1 \mu \mathrm{g}$ $\mathrm{dm}^{-3}$ 以下の検出限界が数 $\mathrm{cm}^{3}$ の液量で容易に達成可能で 
ある・

4）検出感度と試料導入量は比例関係にあるため, 試料 導入量を変化させることで広い濃度領域における測定が可 能である。

5）化学反応性の違いを利用したソフトな分析法である ため，微量成分のスペシエーションにも有効である.

現在, ヨーロッパを中心に, 固相分光流れ分析法の幅広 い分野への応用例が報告されている．著者らが天然水中の 微量金属元素を中心に定量法を開発してきたのに対し，海 外では薬剤や生体試料中の有機物分析への応用例が多い. 今後の展開が期待できる.

\section{文献}

1) M. Fujimoto: Bull. Chem. Soc.Jpn., 27, 48 (1954).

2) 坦花秀武, 村野武男：日本化学雑誌, 75,907 (1954).

3) K. Yoshimura, H. Waki, S. Ohashi: Talanta, 23, 449 (1976).

4) K. Yoshimura, H. Waki : Talanta, 32, 345 (1985).

5) H. Waki, J. Korkisch: Talanta, 30, 95 (1983).

6) H. Waki, S. Noda, M. Yamashita: React. Polym., 7, 227 (1988).

7) S. Yamada, K. Yoshimura: Talanta, 39, 1301 (1992).

8) K. Yoshimura: Anal. Chem., 59, 2922 (1987).

9) 吉村和久: 分析化学 (Bunseki Kagaku), 36, 656 (1987).

10) K. Yoshimura: Analyst, 113, 471 (1988).
11) K. Yoshimura, H. Waki: Talanta, 34, 239 (1987).

12) U. Hase, K. Yoshimura: Anal. Sci., 9, 111 (1993).

13) K. Yoshimura, U. Hase: Analyst, 116, 835 (1991).

14) U. Hase, K. Yoshimura: Analyst, 117, 1501 (1992).

15) K. Yoshimura, S. Matsuoka, H. Waki: Anal. Chim. Acta, 225, 313 (1989).

16) S. Matsuoka, K. Yoshimura, A. Teteda: Anal. Chim. Acta, 317, 207 (1995).

17) K. Yoshimura, S. Nawata, G. Kura: Analyst, 115, 843 (1990).

18) S. Matsuoka, K. Yoshimura, A. Tateda: Mem. Fac. Sci., Ser. C, Kyushu Univ., 18, 169 (1992).

19) K. Yoshimura, S. Matsuoka, Y. Inokura, U. Hase: Anal. Chim. Acta, 268, 225 (1992).

20) F. Lazaro, M. D. Luque de Castro, M. Valcarcel: Anal. Chim. Acta, 219, 231 (1989).

21) K. Yoshimura, S. Matsuoka, T. Tabuchi, H. Waki : Analyst, 117, 189 (1992).

22) K. Yoshimura, S. Yamada: Talanta, 39, 1319 (1992).

23) S. Matsuoka, Y. Tennichi, K. Yoshimura: J. Ion Exchange, 14, (Supplement) 33 (2003).

24) Y. Tennichi, S. Matsuoka, K. Yoshimura: Fresenius J. Anal. Chem., 368, 443 (2000).

25) S. Matsuoka, Y. Tennichi, K. Takehara, K. Yoshimura: Analyst, 124, 787 (1999).

26) S. Saputro，松岡史郎，鶴原照久，中津 悠，竹原 公，馬廷麗，吉村和久：日本分析化学会第 54 年 会講演要旨集, p. 63 (2005).

27) 天日美薰，松岡史郎，吉村和久：日本分析化学会第 49 年会講演要旨集, p. 318 (2000).

\section{要 旨}

試料の前処理法の一つである固相濃縮法は，固相に濃縮した目的成分を脱着後に定量するため，脱着の段 階で目的成分が希釈され，濃縮効率の点からは最善の方法とは言えない。そこで，固相に濃縮された目的成 分に関する情報を直接取り出せれば，高感度定量が可能となると考え，イオン交換体などの少量の固相に濃 縮した着色化学種の光吸収を，直接分光測定する固相分光法を開発した. 更に，数十 $\mathrm{mm}^{3}$ の固相を光路部 に保持させたセルの開発に成功し, 流れ分析を可能にした. 感度は固相と試料溶液の体積比に比例するので, 体積比を大きくとれば溶液法の 100 ～ 1000 倍高感度になり, $10 \mathrm{~cm}^{3}$ 程度の試料溶液を用いれば， $\mu \mathrm{g} \mathrm{dm}^{-3}$ 〜 sub- $\mu \mathrm{g} \mathrm{dm}{ }^{-3}$ レベルの成分を前濃縮なしで定量可能であった. 本法は化学反応を利用するため, 超微量成 分のスペシエーションに適している。またマルチチャンネル検出器を用いれば，多成分系にも適用できるこ とが確認された。 